\title{
QCM Curves:
}
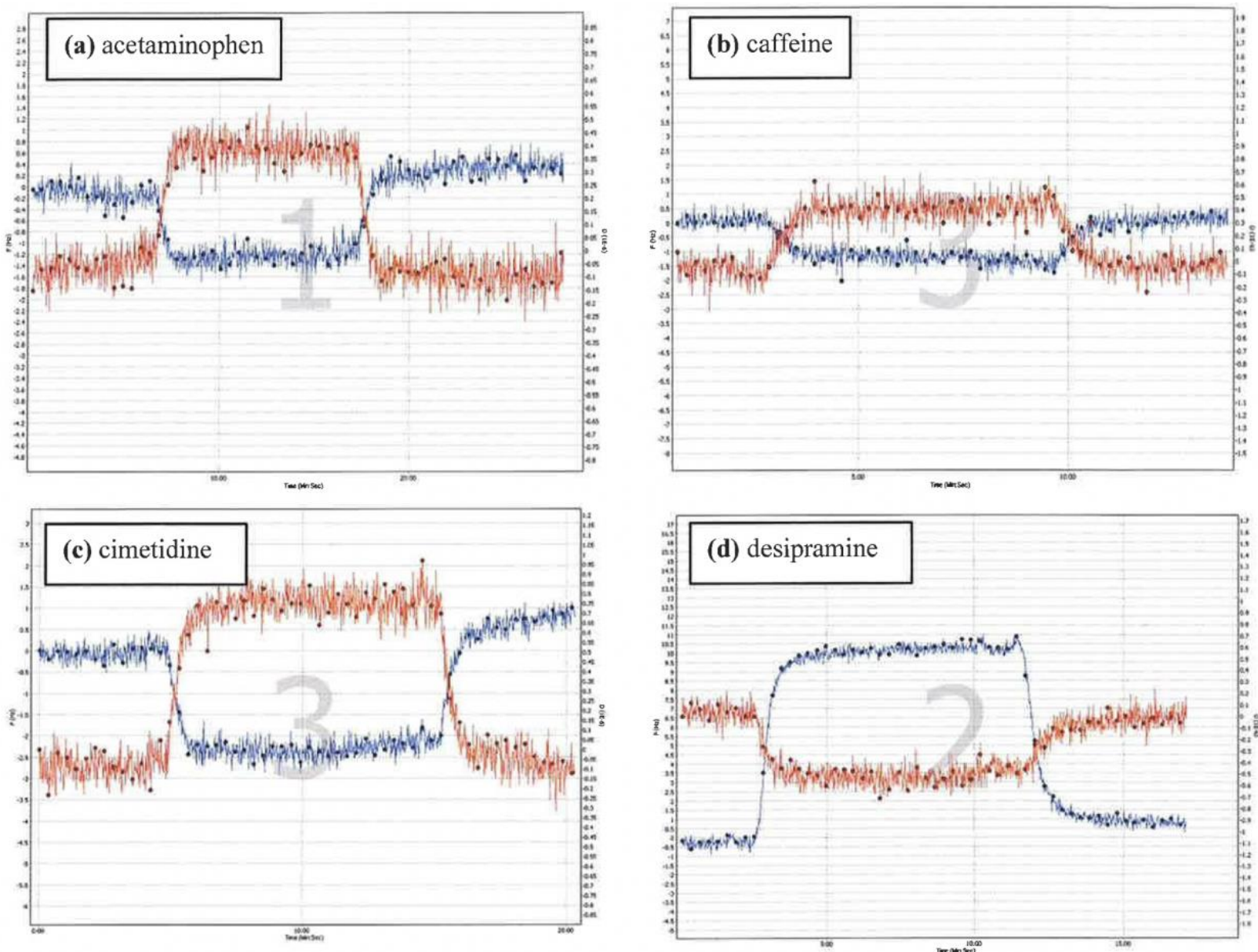

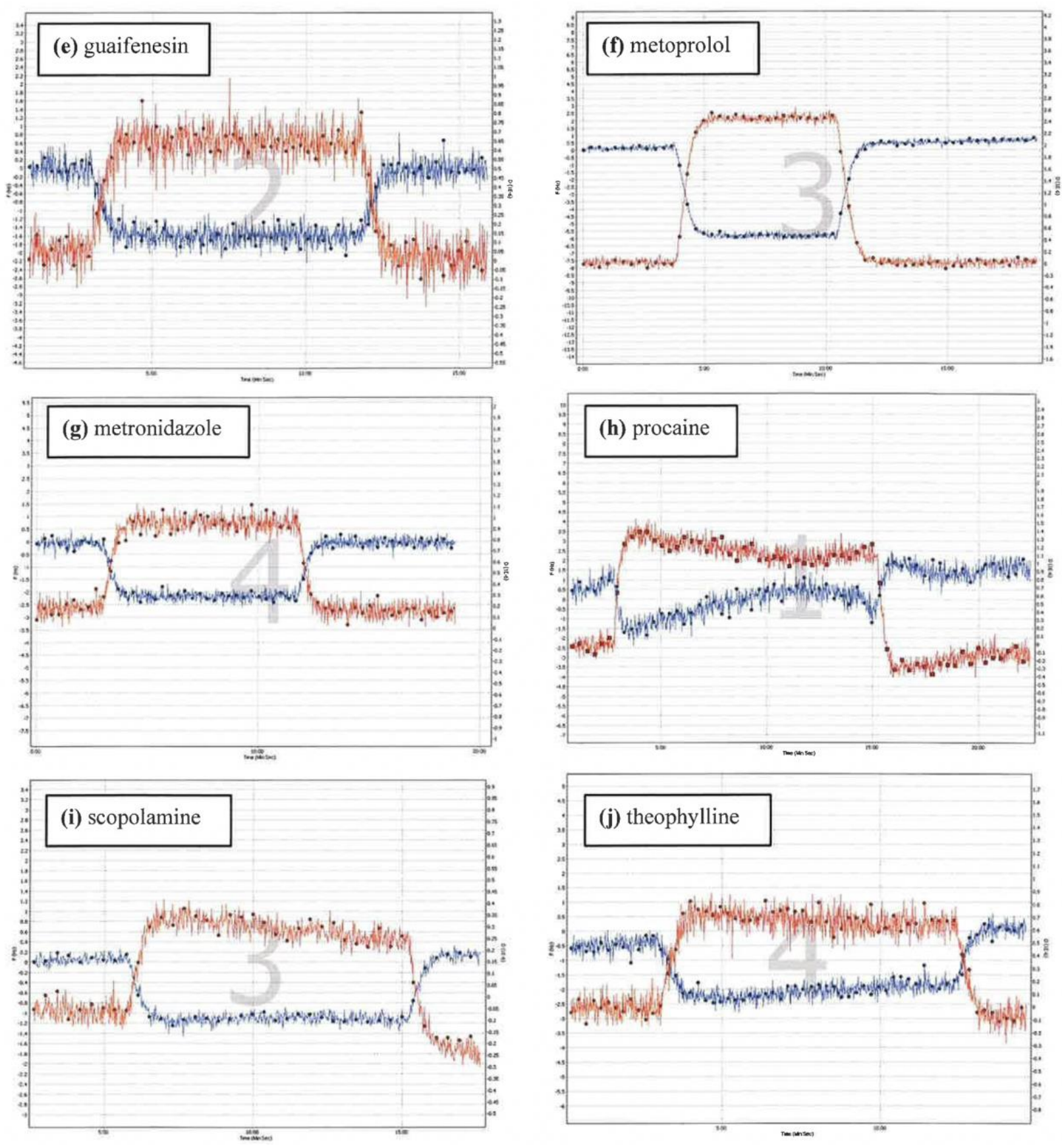